\title{
SATISFACTION OF THE FARMING COMMUNITY TOWARDS THE PERFORMANCE OF AGRICULTURAL EXTENSION SERVICE: A CASE STUDY IN BENJENG SUBDISTRICT OF GRESIK REGENCY, INDONESIA
}

\author{
Hidayat Syarif Imam, Indah Pawana Nur, Nurhayati Tias, Harya Gyska Indah, \\ Hendrarini Hamidah \\ Faculty of Agriculture, UPN "Veteran" Jawa Timur, Surabaya, Indonesia \\ ${ }^{\star}$ E-mail: pawananurindahupnjatim@gmail.com
}

\begin{abstract}
Nowadays, there are still many common weaknesses in the public service that is run by the government officials, so it has not met the quality expected by the public. It is indicated by the presence of public complaints submitted from the mass media, which can give an unfavorable image to the government. Therefore, people's satisfaction with public services need to be measured through the Decree of the Minister of Administrative Reform (KEMENPAN) No. KEP/25M.PAN/2/2004 (Date: February 24, 2004) on General Guidelines for the Arrangement of Community Satisfaction Index of Government Agencies Service Unit. This study is conducted in Benjeng Subdistrict, as one of the sub district in Gresik Regency with a vast area of farm land and high production of rice. The sample of this study is taken by purposive method from the administrator of farmer groups from each group in Benjeng Subdistrict. The measurement of the Community Satisfaction Index is done by calculating an index of 14 indicators of adoption result from KEMENPAN 2004. The result of this study shows that the community in Benjeng Subdistrict is satisfied with the agricultural extension services provided by BP3K of Benjeng Subdistrict with a point of 79.00 and grade B for the service quality. There are 12 factors that support the satisfaction and 2 factors that inhibit the satisfaction. Increasing the effectiveness of teamwork implementation with other parties and reproduces plot need to be done in order to maintain and increase the community satisfaction.
\end{abstract}

\section{KEY WORDS}

Public service, community satisfaction index, community.

The implementation of public services is still faced with conditions that are not in accordance with the needs and changes in various fields of life in the community, nation, and state. The government in the public service reformation era has attempted to improve the public service quality by issuing public satisfaction measurement instrument, or in standard term, the general guidelines for compiling the community satisfaction index of government agency service units. It is written in the Decree of the Minister of Administrative Reform No. KEP/25M.PAN/2/2004 (Date: February 24, 4004) concerning the General Guidelines for the Arrangement of Community Satisfaction Index of Government Agency Service Units. This regulation instructs the regional government or agency to assess how much satisfaction the community has with the services that are provided.

Extension, as a part of an effort to educate the nation and promote public welfare, is included as human right for Indonesian citizens. The government is obliged to provide extension services in the field of agriculture, fisheries, and forestry. The purpose of agricultural extension is to change the main behavior of business actors through increasing their knowledge, skills, attitudes, and motivations (Ministry of Agriculture, 2009). Government extension institutions are mentioned in the Law Number 16 of 2006 concerning the Agricultural, Fisheries, and Forestry Extension System. At the provincial level, the agency is in the form of Extension Coordination Board; at the regency or city level, the agency is in the form of Extension Handling Agency, and at the Subdistrict level it is in the form of Extension Center. 
The Extension Center of Agriculture, Fisheries, and Forestry (BP3K) is an extension implementer and the Regional Government Operational Technical Implementation Unit in the Field of Agricultural, Fisheries, and Forestry Extension that supports agricultural, fisheries, and forestry development programs both at central and regional levels. The effectiveness of the implementation of agricultural extension in Benjeng's BP3K Working Area can be measured through the level of satisfaction of the farming community in obtaining services from the field instructor.

The satisfaction of the farmers community towards the agricultural extension services held by the BP3K in Benjeng Subdistrict is very dependent on the performance provided by the field agriculture instructors. Therefore, it is necessary to study how the performance of the field instructors in providing services to the farming community.

Based on the research problems above, this study aims to calculate the index of satisfaction of the farmer community towards agricultural extension services by BP3K in Benjeng Subdistrict, identify factors that support and inhibit the satisfaction, and provide alternative measures that can be applied.

\section{LITERATURE REVIEW}

Kotler (2005) argues that satisfaction is a feeling of pleasure or disappointment of someone who appears after comparing between his perceptions or impressions of the performance or results of a product and expectations of satisfaction. Satisfaction is a function of perception or impression of performance and expectations. If the performance is below expectations, the customer would not be satisfied. If the performance meets the expectations, customers would be satisfied. If the performance exceeds the expectations, customers would be very satisfied or happy.

Community satisfaction toward the government service performance needs to be continuously measured and compared. One way that can be done to measure community satisfaction with government services is by using the Community Satisfaction Index. The Decree of the Minister of Administrative Reform (KEPMENPAN) Number 25 of 2004 about the General Guidelines for the Arrangement of Community Satisfaction Index mentions the Community Satisfaction Index definition, which is: data and information about the level of community satisfaction obtained from quantitative and qualitative measurement of community opinion in obtaining services from community service providers by comparing their expectations and needs.

Based on the service principles as stipulated in the Decree of Minister of Administrative Reform Number 63/KEP/M.PAN/7/2003, there are 14 indicators that become the minimum element that must exist for the basis of measurement of the Community Satisfaction Index, as written down below:

- Service procedure;

- Service requirements;

- Clarity of service personnel;

- Discipline of service personnel;

- Responsibility of service personnel;

- Speed of service;

- Fair service;

- Courtesy and friendliness of servers or officers;

- Fairness of service fees;

- Certainty of service fees;

- Certainty of service schedule;

- Environmental comfort;

- Service security.

Agricultural extension is a policy tool that can be used by the government to encourage agricultural development. The main task of agricultural extension agents is to carry out agricultural extension activities to develop farmers' ability to master, utilize, and apply new 
technologies, so that they are able to work better, earn bigger profit, and foster a more prosperous family by farming. The main tasks of the extension agents are:

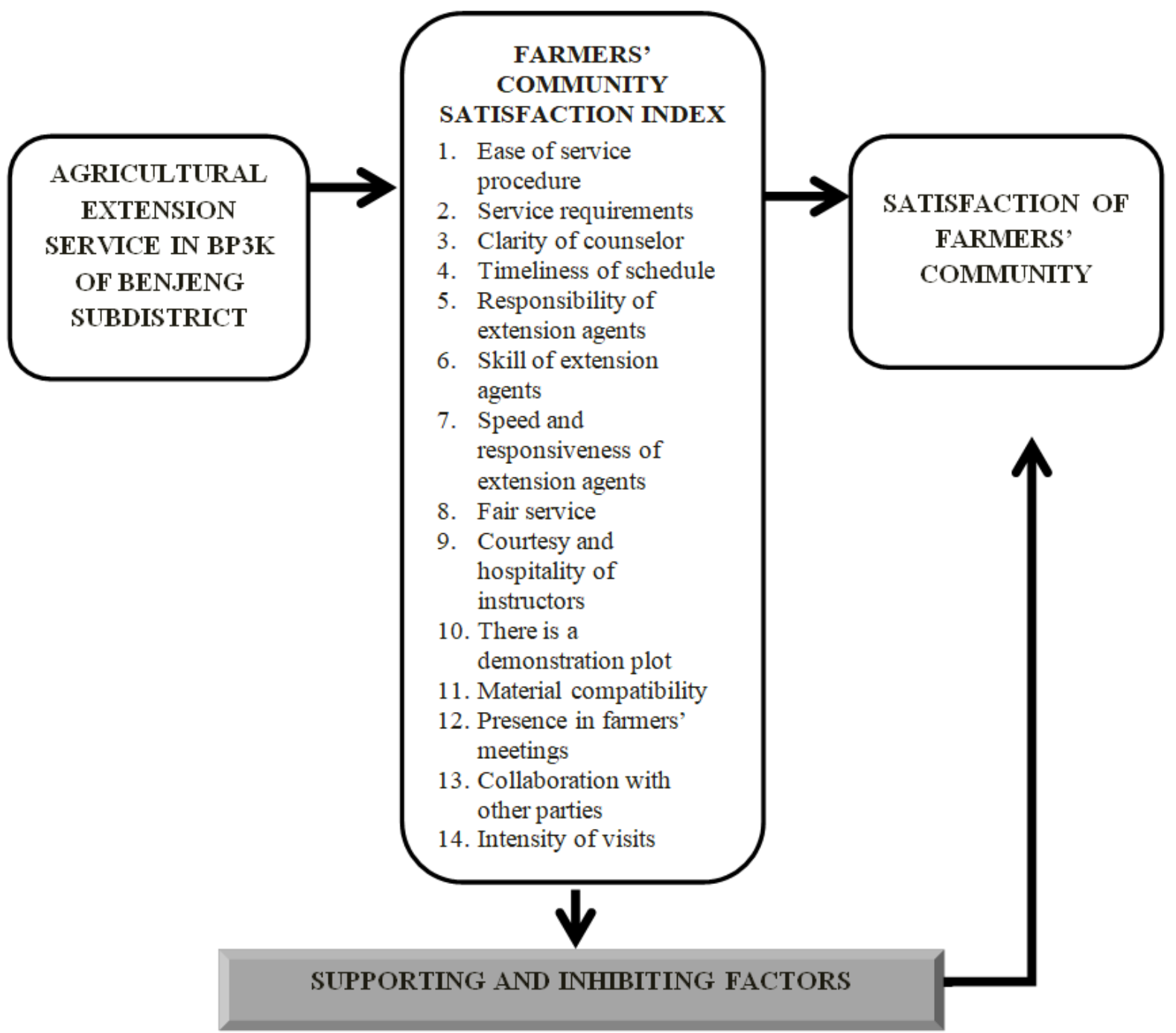

Figure 1 - Conceptual Framework

The hypotheses proposed in this study are as follows:

- It is suspected that the farming community in Benjeng Subdistrict is satisfied with the agricultural extension services done by the BP3K of Benjeng Subdistrict;

- It is assumed that the indicators of ease of procedure, extension requirements, clarity of agents, accuracy of schedules, responsibilities of agents, agents' ability, agents' responsiveness, service justice, courtesy of agents, material suitability, and the presence of extension agents in meetings become a factor that supports the satisfaction of farmer community with agricultural extension services done by BP3K of Benjeng Subdistrict.

\section{METHODS OF RESEARCH}

This study is conducted using qualitative method. The data collection is done by indepth interviews in order to obtain systematic data and information collection about a very specific particular problem. The location of this study is in Benjeng Subdistrict, Gresik Regency that is done purposively, considering that Benjeng Subdistrict, Gresik Regency is an area with the majority of the people work in agriculture and most of the land are used for 
agricultural purposes. The samples are also chosen purposively, by taking the management of farmer groups in the Subdistrict with the amount of 80 samples.

The value of Community Satisfaction Index (CSI) is calculated using "weighted average value" of each service element. To obtain the service units of the community satisfaction index (CSI), the weighted average value approach is used. In order to ease the interpretation of the CSI assessment, which is between 25 to100, the results of the assessment above are converted with a base value of 25 .

Since the service units have different characteristics, it is possible for each service unit to: add elements that are considered relevant; give different weights to 14 (fourteen) dominant elements in the service unit, as long as the number of weights of all elements is 1 .

Table 1 - Table of Perception Value, CSI Interval, CSI Conversion Interval, Quality Service, Service Unit Performance, Satisfaction toward Service

\begin{tabular}{llllll}
\hline $\begin{array}{l}\text { Perception } \\
\text { Value }\end{array}$ & $\begin{array}{l}\text { CSI } \\
\text { Interval } \\
\text { Value }\end{array}$ & $\begin{array}{l}\text { CSI Interval } \\
\text { Conversion Value }\end{array}$ & $\begin{array}{l}\text { Service } \\
\text { Quality }\end{array}$ & $\begin{array}{l}\text { Service Unit } \\
\text { Performance }\end{array}$ & $\begin{array}{l}\text { Satisfaction Toward } \\
\text { Service }\end{array}$ \\
\hline 1 & $1,00-1,75$ & $25-43,75$ & D & Not good & Not satisfied \\
2 & $1,76-2,50$ & $43,76-62,50$ & C & Not good & Less satisfied \\
3 & $2,51-3,25$ & $62,51-81,25$ & B & Good & Satisfied \\
4 & $3,26-4,00$ & $81,26-100$ & A & Very good & Very satisfied \\
\hline
\end{tabular}

Source: KEMENPAN No. KEP/25/M.PAM/2/2004.

\section{RESULTS AND DISCUSSION}

Based on the measurement toward 14 service indicators, the calculation result of Community Satisfaction Index (CSI) of agricultural extension service in Benjeng Subdistrict is obtained. It refers to the data processing of the Community Satisfaction Index per service indicator (data on the Appendix), which is presented in Table 2 as follows:

Table 2 - Public Satisfaction Index Calculation per Service Indicator

\begin{tabular}{|c|c|c|c|c|c|c|}
\hline No. & Service Indicator & $\begin{array}{l}\text { Total } \\
\text { Value }\end{array}$ & $\begin{array}{l}\text { CSI } \\
\text { Value }\end{array}$ & $\begin{array}{l}\text { CSI } \\
\text { Conversion } \\
\text { Value }\end{array}$ & $\begin{array}{l}\text { Quality of } \\
\text { Services }\end{array}$ & Performance \\
\hline 1 & $\begin{array}{l}\text { Ease of service procedure } \\
\text { procedures }\end{array}$ & 284 & 3,55 & 88,75 & A & Very good \\
\hline 2 & Service requirements & 286 & 3,57 & 89,25 & A & Very good \\
\hline 3 & Clarity of information delivery & 279 & 3,48 & 87 & A & Very good \\
\hline 4 & Timeliness of extension schedule & 291 & 3,63 & 90,75 & A & Very good \\
\hline 5 & $\begin{array}{l}\text { Responsibility of extension } \\
\text { agents }\end{array}$ & 261 & 3,26 & 81,5 & $A$ & Very good \\
\hline 6 & Skill of extension agents & 262 & 3,27 & 81,75 & A & Very good \\
\hline 7 & $\begin{array}{l}\text { Speed and responsiveness of } \\
\text { extension agents }\end{array}$ & 268 & 3,35 & 83,75 & A & Very good \\
\hline 8 & Fair services & 264 & 3,3 & 82.5 & A & Very good \\
\hline 9 & $\begin{array}{l}\text { Courtesy and hospitality of } \\
\text { instructors }\end{array}$ & 279 & 3,48 & 87 & A & Very good \\
\hline 10 & There is a demonstration plot & 192 & 2,4 & 60 & C & Not good \\
\hline 11 & Material compatibility & 274 & 3,42 & 85,5 & A & Very good \\
\hline 12 & Presence in farmers' meetings & 265 & 3,31 & 82,75 & $A$ & Very good \\
\hline 13 & Cooperation with other parties & 177 & 2,06 & 51,5 & C & Not good \\
\hline \multirow[t]{2}{*}{14} & Intensity of visit & 254 & 3,17 & 79,25 & $\mathrm{~B}$ & Good \\
\hline & Total Amount & 3.636 & 45.4 & 3.16 & . & \\
\hline
\end{tabular}

Source: Processed Primary Data, 2016.

To ease the interpretation for the CSI assessment, which is between 25 to 100 , the total results of CSI Conversion value is converted with the base value of 25 .

The CSI Conversion value $=3.16 \times 25=79.00$. Furthermore, the result of the conversion value of the Community Satisfaction Index (CSI) toward extension services in the 
Agricultural, Fisheries, and Forestry Extension Services of Benjeng Subdistrict is adjusted with a categorization of service quality based on the index shown in Table 3 as follows:

Table 3 - Categorization of Service Quality

\begin{tabular}{llll}
\hline CSI Interval Values & CSI Conversion Interval Value & Quality Service & Service Unit Performance \\
\hline $1,00-1,75$ & $25,00-43,75$ & D & NOT SATISFIED \\
$1,76-2,50$ & $43,76-62,50$ & C & LESS SATISFIED \\
$2,51-3,25$ & $62,51-81,25$ & B & SATISFIED \\
$3,26-4,00$ & $81,26-100,00$ & A & VERY SATISFIED \\
\hline
\end{tabular}

Source: KEPMENPAN No. KEP/25/M.PAM/2/2004.

Table 4 - Alternative Efforts

\begin{tabular}{|c|c|c|c|}
\hline No & Indicator & $\begin{array}{l}\text { Alternative Efforts that can be done to Maintain and } \\
\text { Increase the Satisfaction of the Farming Community }\end{array}$ & $\begin{array}{l}\text { Importance Assessment } \\
\text { According to the Respondent }\end{array}$ \\
\hline 1. & $\begin{array}{l}\text { Ease of extension } \\
\text { procedures }\end{array}$ & $\begin{array}{l}\text { Extension agents are easily found by farmers } \\
\text { Extension agents are easily contacted via telephone, } \\
\text { SMS, or other social media } \\
\text { Maintain the ease of service that has been } \\
\text { implemented }\end{array}$ & Standard \\
\hline 2. & No extension requirements & $\begin{array}{l}\text { Maintain the rules that have been implemented by } \\
\text { providing counseling without additional condition }\end{array}$ & Standard \\
\hline 3. & $\begin{array}{l}\text { Delivery of clear information } \\
\text { by extension agents }\end{array}$ & $\begin{array}{l}\text { Use simple language that is easy of understand } \\
\text { Convey information with sources and clear references } \\
\text { Use props that are easy to practice }\end{array}$ & Very important \\
\hline 4. & $\begin{array}{l}\text { Timeliness of extension } \\
\text { schedules }\end{array}$ & $\begin{array}{l}\text { Create a short, medium, and long term work planning } \\
\text { schedule } \\
\text { Always coordinate with farmer group administrators } \\
\text { before conducting counseling } \\
\text { Hold regular meetings }\end{array}$ & Important \\
\hline 5. & $\begin{array}{l}\text { Responsibility of extension } \\
\text { agents }\end{array}$ & $\begin{array}{l}\text { Evaluate and monitor when problems occur in } \\
\text { agriculture } \\
\text { Identify and formulate solutions to problems that } \\
\text { cannot be resolved by farmers } \\
\text { Maintain what has been considered good by the } \\
\text { farming community }\end{array}$ & Very important \\
\hline 6. & $\begin{array}{l}\text { Competency of extension } \\
\text { agents }\end{array}$ & $\begin{array}{l}\text { Always attend training, comparative studies, and } \\
\text { seminars to improve insight and skills }\end{array}$ & Important \\
\hline 7. & $\begin{array}{l}\text { Responsiveness of extension } \\
\text { agents }\end{array}$ & $\begin{array}{l}\text { Equip themselves with extensive insight into new } \\
\text { information and technologies related to agriculture, to } \\
\text { increase intensification of production } \\
\text { Establish cooperation with other institutions or NGOs } \\
\text { that can provide training in the form of excellent } \\
\text { service } \\
\text { Utilizing information and communication technology } \\
\text { Maintaining speed and response that has been rated } \\
\text { well by the farming community }\end{array}$ & Very important \\
\hline 8. & $\begin{array}{l}\text { Fairness of service of } \\
\text { extension agents }\end{array}$ & $\begin{array}{l}\text { Providing extension services to all farming } \\
\text { communities without distinguishing farmers who } \\
\text { become administrator of the Gapoktan or not }\end{array}$ & Standard \\
\hline 9. & $\begin{array}{l}\text { Courtesy and friendliness of } \\
\text { extension agents }\end{array}$ & $\begin{array}{l}\text { Follow local values, culture, and customs } \\
\text { Use local language in communicating } \\
\text { Respect and assist farmers in all problems }\end{array}$ & Standard \\
\hline 10. & $\begin{array}{l}\text { Material compatibility with the } \\
\text { needs of the farming } \\
\text { community }\end{array}$ & $\begin{array}{l}\text { Choosing material in accordance with the problems or } \\
\text { circumstances faced by farmers } \\
\text { Material variations and renewal } \\
\text { Provide materials that contain new science and } \\
\text { technology for the farming community }\end{array}$ & Important \\
\hline 11. & $\begin{array}{l}\text { The presence of extension } \\
\text { agents at every farmers' } \\
\text { meeting }\end{array}$ & $\begin{array}{l}\text { Participate in all agricultural community activities } \\
\text { related to agriculture } \\
\text { In the farmers' meeting, the instructor gives suggestion }\end{array}$ & Very important \\
\hline
\end{tabular}

Based on the categorization of service quality in Table 3 above, the Agricultural, Fisheries, and Forestry Extension Center of Benjeng Subdistrict obtained the CSI Conversion Interval Value of 79.00. The service unit performance of Agricultural, Fisheries, and Forestry Extension Center of Benjeng Subdistrict is in the 'B' grade with 'GOOD' category, and the farming community in Benjeng Subdistrict is satisfied with the service that 
is provided. The supporting and inhibiting factors that affect the satisfaction of the farming community toward agricultural extension services in BP2K of Benjeng Subdistrict are:

Supporting factors: Ease of extension procedures; No extension requirements; Delivery of clear information by extension agents; Timeliness of extension schedules; Very responsible extension agents; Competent extension agents; Responsive extension agents; Fair services in getting extension services; Compatibility of the material with the needs of the farming community; Agents' presence at every farmers' meeting/event.

Inhibiting factors: Lack of demonstration plots and extension equipment; Lack of effective cooperation with other parties, such as follow-up of cooperation that has not been fully implemented; Lack of intensity of extension visits.

The alternative efforts that can be applied from the problems and conditions in order to maintain and increase the satisfaction of the farming community towards the performance of agricultural extension in the BP3K of Benjeng Subdistrict from the 14 indicators that have been discussed is explained in Table 4.

\section{CONCLUSION}

From the results and discussion of the study about the analysis of Farming Community Satisfaction Index on the performance of agricultural extension services in BP3K of Benjeng Subdistrict, it can be concluded that the service that has been provided by the government apparatus, in which the extension agents in this study have been running well. The farming communities are also satisfied with the service, which also shown from 12 service indicators that are considered good with 'B' grade for the service quality.

The supporting and inhibiting factors that affect the satisfaction of the farming community toward the agricultural extension service in BP3K of Benjeng Subdistrict are:

Supporting Factors:

- Ease of extension procedures;

- No extension requirements;

- Delivery of clear information by extension agents;

- Timeliness of extension schedules;

- Very responsible extension agents;

- Competent extension agents;

- Responsive extension agents;

- Fair services in getting extension services;

- Compatibility of the material with the needs of the farming community;

- Agents' presence at every farmers' meeting/event. Inhibiting Factors:

- Lack of demonstration plots and extension equipment;

- Lack of effective cooperation with other parties, such as follow-up of cooperation that has not been fully implemented;

- Lack of intensity of extension visits.

The alternative efforts that can be done by the BP3K of Benjeng Subdistrict to maintain and increase the satisfaction of the farming community toward the performance of agricultural extension service based on 14 indicators that have been tested is by maintaining the service performance from 11 indicators that have been assessed good by the farming community, and carry out performance improvement toward 3 indicators with low score given by the community.

\section{REFERENCES}

1. Abubakar AN. dan Siregar. 2010. Kualitas Pelayanan Penyuluhan dan Kepuasan Petani dalam Penanganan dan Pengolahan Hasil Ubi Jalar (Ipomoea batatas L.). Jurnal Penyuluhan Pertanian 5 (1).

2. Al-zahrani, K. H., et al. (2019) 'Saudi Journal of Biological Sciences Perceptions of wheat 
farmers toward agricultural extension services for realizing sustainable biological yields', Saudi Journal of Biological Sciences. King Saud University, (xxxx), pp. 2-7. doi: 10.1016/j.sjbs.2019.02.002.

3. Fagi A.M. 2001. Food Agricultural Extension System. Participatory Extension Revitalization thus minded: Agribusiness. Working Paper 08/2001. IAARD

4. Feliciano, D., Nayak, D. R., Vetter, S. H., \& Hillier, J. (2017). CCAFS-MOT-A tool for farmers, extension services and policy-advisors to identify mitigation options for agriculture. Agricultural systems, 154, 100-111.

5. Ibrahim A. 2008. Theory and Concepts and Implementation of Public Service. Bandung: Mandar Maju.

6. Kansiime, M. K., Alawy, A., Allen, C., Subharwal, M., Jadhav, A., \& Parr, M. (2019). Effectiveness of mobile agri-advisory service extension model: Evidence from Direct2Farm program in India. World Development Perspectives, 13, 25-33.

7. Kepmenpan Number 25 Year 2004 on General Guidelines for Preparation of Public Satisfaction Index And Services Unit Government Agencies

8. Kepmenpan Number. 63 of 2003 on General Guidelines for the Implementation of Public Service

9. Kemenpan Number 81 of 1993 on General Guidelines for the Implementation of Public Service

10. Kotler, P. 2005. Marketing Management, Issue Eleven, Volume 1.2. Jakarta: Gramedia Group Index

11. Khatri-Chhetri, A., Pant, A., Aggarwal, P. K., Vasireddy, V. V., \& Yadav, A. (2019). Stakeholders prioritization of climate-smart agriculture interventions: Evaluation of a framework. Agricultural Systems, 174, 23-31.

12. Kurniawan, J. Rogan and Mokhammad Najib. 2008. Paradigm Public Service Policy. Malang: In.Trans.

13. Law of the Republic of Indonesia Number 16 Chapter 2 Article 4 of 2006 on Agricultural Extension System, Fisheries and Forestry

14. Mosher, A.T., 1997. Moving and Build Agriculture. Yasa Guna. Jakarta

15. Nataliningsih. 2013. Dampak Toward Participatory Agricultural Extension Farmers Welfare Improvement Starter. Universitas Bandung Raya.

16. Olorunfemi, T. O., Olorunfemi, O. D., \& Oladele, O. I. (2019). Determinants of the involvement of extension agents in disseminating climate smart agricultural initiatives: Implication for scaling up. Journal of the Saudi Society of Agricultural Sciences.

17. Padmowihardjo, S., 1996, the Agricultural Extension Program. Jakarta: Universitas Terbuka.

18. Soedijanto. 1996. Administration of Agricultural Extension. Universitas Terbuka. Jakarta.

19. Suwandi. 2006. Participatory Extension. Bogor: Cekza Blog. 